\title{
Warmed diluent speeds dantrolene reconstitution
}

\author{
[Le diluant réchauffé accélère la reconstitution du dantrolène]
}

Laura W. Mitchell PhD, ${ }^{*}$ Barbara L. Leighton MD $\dagger$

Purpose: To define more completely the aqueous solubility of dantrolene in order to devise faster reconstitution techniques for use during malignant hyperthermia episodes.

Methods: To determine Beer's law compliance and the extinction coefficient, we measured the spectrophotometric absorbance at $385 \mathrm{~nm}$ of known dantrolene solutions. We added small aliquots of sterile water USP $\left(\mathrm{pH} 5.3 ; 15-40^{\circ} \mathrm{C}\right)$ or buffered water $\left(20^{\circ} \mathrm{C}\right.$; $\mathrm{pH}$ 6.8-9.I) to dantrolene, mechanically agitated and filtered the solutions, and spectrophotometrically determined concentration. To simulate clinical reconstitution conditions, we added sterile water, $60 \mathrm{~mL}$, at temperatures between 15 and $40^{\circ} \mathrm{C}$ to dantrolene vials and measured the manual shaking time needed to create a) a suspension of small particles, and b) a clear solution.

Results: A plot of UV-vis absorbance at $385 \mathrm{~nm}$ vs dantrolene concentration was linear and went through the origin; the extinction coefficient is $16.1 \mathrm{mM}^{-1}$. At $20^{\circ} \mathrm{C}$, dantrolene is nearly insoluble below $\mathrm{pH}$ 8.8. Dantrolene is 2.8 times more soluble in $0.1 \mathrm{M}$ THAM (tris-(hydroxymethyl)aminomethane) than in sterile water at $\mathrm{pH}$ 9. I. Dantrolene is 6.7 times more soluble in $40^{\circ} \mathrm{C}$ than in $20^{\circ} \mathrm{C}$ water at $\mathrm{pH} 9.5$ (the $\mathrm{pH}$ of reconstituted dantrolene). Under clinical conditions, water temperature altered the time to create a clear solution but not a suspension (60 sec).

Conclusion: Diluting dantrolene with $40^{\circ} \mathrm{C}$ water rather than operating-room temperature water $\left(20^{\circ} \mathrm{C}\right.$ or below) would speed dantrolene reconstitution.

Objectif : Définir plus adéquatement la solubilité aqueuse du dantrolène dans le but d'élaborer des techniques de reconstitution plus rapide, utilisables au cours des crises d'hyperthermie maligne.

Méthode : Nous avons déterminé la compliance à la loi de Beer et le coefficient d'extinction en mesurant l'absorption spectrophotométrique à $385 \mathrm{~nm}$ de solutions de dantrolène connues. Nous avons ajouté au dantrolène quelques aliquots d'eau stérile USP ( $\mathrm{pH}$ 5,3; 15 - $40{ }^{\circ} \mathrm{C}$ ) ou d'eau tamponnée $\left(20^{\circ} \mathrm{C} ; \mathrm{pH} 6,8\right.$ - 9,1), agité mécaniquement et filtré les solutions et déterminé la concentration par spectrophotométrie. Nous avons ajouté de l'eau stérile, $60 \mathrm{~mL}$, aux bouteilles de dantrolène afin de simuler les conditions cliniques de reconstitution à des températures de 15 à $40{ }^{\circ} \mathrm{C}$ et nous avons mesuré le temps d'agitation manuelle nécessaire pour créer a) la suspension de petites particules et b) une solution cristalline.

Résultats : Un tracé de l'absorption UV-vis à $385 \mathrm{~nm}$ vs la concentration de dantrolène était linéaire et passait par l'origine ; le coefficient d'extinction est de $16,1 \mathrm{nM}^{-1}$. À $20^{\circ} \mathrm{C}$, le dantrolène est presque insoluble pour un $\mathrm{pH}$ plus bas que 8,8 . Le dantrolène est 2,8 fois plus soluble dans $0,1 \quad M$ de THAM (tris(hydroxyméthyl)aminométhane) que dans de l'eau stérile dont le $\mathrm{pH}$ est de 9, I. Le dantrolène est 6,7 fois plus soluble dans de l'eau à 40 ${ }^{\circ} \mathrm{C}$ plutôt qu'à $20^{\circ} \mathrm{C}$ pour un pH de 9,5 (le pH du dantrolène reconstitué). Dans des conditions cliniques, la température de l'eau modifie le temps nécessaire à la création d'une solution cristalline mais non celui d'une suspension (60 sec).

Conclusion : La dilution du dantrolène avec de l'eau à $40^{\circ} \mathrm{C}$ plutôt que de l'eau à la température ambiante de la salle d'opération $\left(20^{\circ} \mathrm{C}\right.$ ou moins) devrait accélérer la reconstitution du dantrolène.

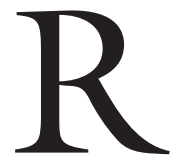

ECONSTITUTING dantrolene fast enough to reverse malignant hyperthermia $(\mathrm{MH})$ in an adult is a difficult task. Gronert et al. advise that this job usually requires the full-time efforts of three or four people. ${ }^{1}$ The only iv dantrolene formulation available in North America (Dantrium $\AA$, Procter \& Gamble Pharmaceuticals, Cincinnati, OH, USA; each vial contains dantrolene $20 \mathrm{mg}$, mannitol $3 \mathrm{~g}$, and sodium hydroxide to ensure that the reconstituted solution has a $\mathrm{pH}$ of 9.5), is poorly water soluble. However, water is the recommended dantrolene diluent.

From the Department of Chemistry, ${ }^{*}$ St. Joseph's University, Philadelphia, Pennsylvania and the Department of Anesthesiology, $\uparrow$ MCP Hahnemann University, Philadelphia, Pennsylvania, USA.

Address correspondence to: Dr. Barbara L. Leighton, Department of Anesthesiology, 660 S. Euclid Ave, Campus Box 8054, St Louis, Missouri 63110, USA. Phone: 314-362-2356; Fax: 314-362-1185; E-mail: bleigh@alumni.princeton.edu

Received from and supported only by the Department of Chemistry, St. Joseph's University, Philadelphia, PA and the Departments of Anesthesiology, MCP Hahnemann University, Philadelphia PA and Weill Medical College of Cornell University, New York, NY, USA. Presented in part at the 1999 annual meeting of the American Society of Anesthesiologists.

Accepted publication May 23, 2002.

Revision accepted August 26, 2002. 
Heat speeds dantrolene dissolution. If dantrolene does not dissolve readily, textbooks recommend heating the dantrolene vial either by immersing the vial in hot water or gently autoclaving the vial. ${ }^{1}$ This could be hazardous, for one could easily apply excessive heat (particularly with autoclaving) and produce a dantrolene solution hot enough to cause burns., ${ }^{2,3}$ Also, both suggested heating techniques take time. An alternative way to facilitate dantrolene dissolution might be to preheat the sterile water diluent to an effective but thermally safe (i.e., $\leq 40^{\circ} \mathrm{C}$ ) temperature. However, there is insufficient information on the temperature dependence of dantrolene solubility to determine whether such preheating might be clinically useful. In addition, the $\mathrm{pH}$ adjustments recommended by some authors to assist dantrolene preparation have little support. ${ }^{4,5}$ Therefore, we systematically studied the solubility of dantrolene as a function of temperature and $\mathrm{pH}$.

\section{Methods \\ Materials}

The dantrolene used to confirm compliance with Beer's law was obtained from Sigma-Aldrich Chemical Co., St. Louis, MO, USA. We obtained the dantrolene used in temperature, $\mathrm{pH}$ and THAM dissolution experiments (Dantrium ${ }^{\circledR}$ Intravenous, Procter \& Gamble Pharmaceuticals, Cincinnati, OH, USA) at the time of clinical expiration (April 30, 1999) from City Avenue Hospital, Philadelphia, PA, USA and performed these experiments May 11-12, 1999. We obtained phosphate buffer (sodium potassium phosphate), concentrated $\mathrm{HCl}$, THAM (tris-(hydroxymethyl)aminomethane), and an Accumet $\mathrm{pH}$ meter from Fisher (ACS grade; Fisher Scientific, Malvern, PA, USA). THAM and phosphate buffer solutions were diluted with house distilled water that was additionally purified by passage through a Barnstad water polisher. All other water used was sterile water, USP. Cloudy suspensions and solutions containing particles were filtered through $0.2 \mu \mathrm{M}$ syringe filters with cellulose acetate membranes (Fisher Scientific, Malvern, PA, USA).

\section{Measurement of ultraviolet-visible spectra of dantrolene} solutions and calculation of dantrolene concentration We obtained ultraviolet-visible (UV-vis) spectra in quartz cuvettes using a Hitachi U2001 spectrophotometer (Pleasanton, CA, USA) scanning from 190 $\mathrm{nm}$ to $1100 \mathrm{~nm}$ at a scan speed of $800 \mathrm{~nm} \cdot \mathrm{min}^{-1}$ using the appropriate buffer as a reference. To determine compliance with Beer's law and dantrolene's extinction coefficient, we measured the maximal absorbance at $385 \mathrm{~nm}$ of solutions of pure dantrolene (12-120 $\mu \mathrm{M})$ dissolved in water. We calculated the concentra- tions of the solutions in parts 1 and 2 using absorbance data at $385 \mathrm{~nm}$.

\section{Part 1. Dantrolene solubility with varying $\mathrm{pH}$}

We determined the effect of solute $\mathrm{pH}$ on dantrolene solubility by adding $0.5-1.0 \mathrm{~mL}$ aliquots (up to a total volume of $10 \mathrm{~mL}$ ) of $0.1 \mathrm{M}$ THAM (pH 7.1-9.1), 0.1 $\mathrm{M}$ phosphate ( $\mathrm{pH} 6.8$ and 7.2), or sterile water, USP (pH 5.3) to $0.33-0.35 \mathrm{~g}$ Dantrium ${ }^{\circledR}$. Solutions were mechanically agitated to speed dissolution. Aliquots were added until a clear solution formed or a maximum volume of $10 \mathrm{~mL}$ was reached. Solutions that were cloudy with $10 \mathrm{~mL}$ diluent were filtered. Solution $\mathrm{pH}$ was redetermined after reconstitution. We compared the optical densities for dantrolene dissolved in sterile water vs 0.1 M THAM at $\mathrm{pH} 9.1$.

\section{Part 2. Dantrolene solubility with varying water tem- perature}

In order to assess whether dantrolene stability depended on the temperature of the water used for reconstitution, we measured absorbance at $385 \mathrm{~nm}$ immediately and $24 \mathrm{hr}$ after reconstitution for all solutions mixed in part 2. Solutions were stored at $20^{\circ} \mathrm{C}$ after reconstitution. The diluent was sterile water, USP ( $\mathrm{pH}$ 5.3).

\section{A. LABORATORY CONDITIONS}

We determined the minimum fluid volume in which the contents of a Dantrium ${ }^{\circledR}$ vial dissolved when the initial temperature of the sterile water diluent was 20 , $25,30,37$, or $40^{\circ} \mathrm{C}$. We performed one experiment at each diluent temperature. In each experiment, we incrementally added $2-5 \mathrm{~mL}$ aliquots of sterile water, USP, to a previously unopened Dantrium ${ }^{\circledR}$ vial, thoroughly shook the vial manually and with a mechanical agitator for at least $30 \mathrm{sec}$ after each aliquot, and then visually inspected the vial to determine whether the vial contents had dissolved. If the vial contents did not fully dissolve in $60 \mathrm{~mL}$ of water, the resulting solution was filtered to remove insoluble material.

\section{B. Simulated Clinical CONDitions}

Sterile water, USP, $60 \mathrm{~mL}$, was added at $15,20,25,30$, 37 , or $40^{\circ} \mathrm{C}$ to Dantrium ${ }^{\circledR}$ vials and the duration of manual shaking needed to dissolve the contents was determined. We did not use a mechanical agitator as one is usually not available in the operating room. The solutions were observed continuously to determine: a) when a clear solution formed; and b) when a suspension with small but not large particles formed. Manual shaking was discontinued for five seconds every $30 \mathrm{sec}$ to facilitate visual inspection. We decided that dissolution 


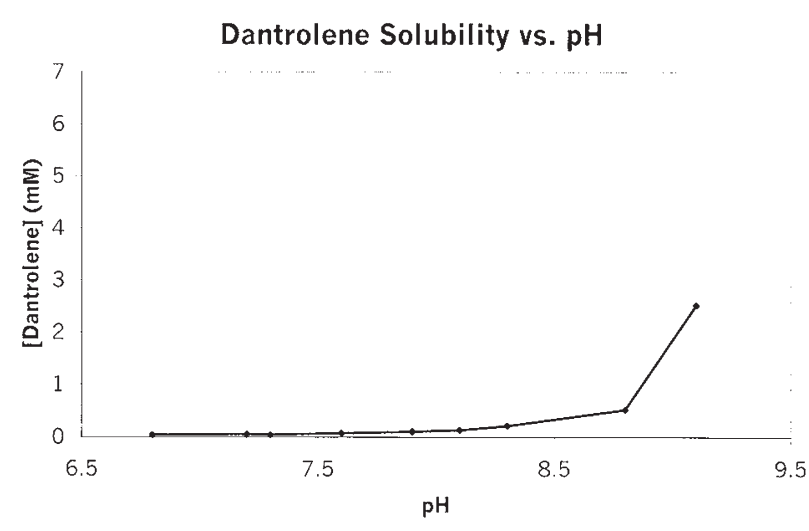

FIGURE 1 Dantrolene solubility $v s \mathrm{pH}$. Maximal dantrolene concentrations in $0.1 \mathrm{M}$ phosphate $(\mathrm{pH} 6.8$ and 7.2) and $0.1 \mathrm{M}$ THAM ( $\mathrm{pH} 7.1-9.1$ ) were determined spectrophotometrically. When dantrolene is reconstituted as recommended with $60 \mathrm{~mL}$ of water, the dantrolene concentration is about $1 \mathrm{mM}$.

times longer than three minutes were clinically impractical and did not shake vials longer than $180 \mathrm{sec}$. Vials in which a clear solution had not formed by $180 \mathrm{sec}$ were observed again after $60 \mathrm{~min}$ storage at $20^{\circ} \mathrm{C}$.

\section{Results}

A plot of UV-vis absorbance at $385 \mathrm{~nm}$ vs dantrolene concentration was linear and went through the origin, indicating compliance with Beer's law. We obtained an extinction coefficient of $16.1 \mathrm{mM}^{-1}$.

\section{Part 1. Dantrolene solubility with varying $p H$}

Dantrolene is nearly insoluble at $\mathrm{pH}$ values below 8.8 at $20^{\circ} \mathrm{C}$ (Figure 1 ). At $20^{\circ} \mathrm{C}$ and $\mathrm{pH} 9.1$, dantrolene is 2.8 times more soluble in 0.1 M THAM than in sterile water $(2.52$ vs $0.88 \mathrm{mM})$.

\section{Part 2. Dantrolene solubility with varying water tem- perature}

Absorption at $385 \mathrm{~nm}$ did not change over $24 \mathrm{hr}$ in any of the part 2 solutions.

\section{A. LABORATORY CONDitions}

Dantrolene optical density at $385 \mathrm{~nm}$ increased linearly with temperature between $20^{\circ} \mathrm{C}$ and $40^{\circ} \mathrm{C}$ at $\mathrm{pH}$ 9.5 (Figure 2). Dantrolene is 6.7 times more soluble in $40^{\circ} \mathrm{C}$ water than in $20^{\circ} \mathrm{C}$ water.

\section{B. Simulated Clinical Conditions}

The time required to produce a suspension of small particles (about $60 \mathrm{sec}$ ) was not altered by the tem-

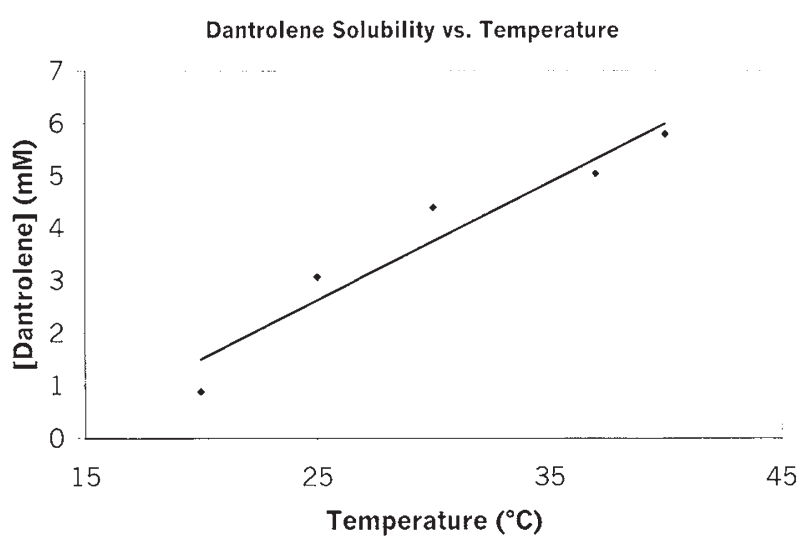

FIGURE 2 Dantrolene solubility $p s$ temperature. Maximal dantrolene concentrations in sterile water, USP $\left(20-40^{\circ} \mathrm{C}\right)$ were determined spectrophotometrically. The $y$-axis scale of this figure is the same as that in Figure 1. When dantrolene is reconstituted as recommended with $60 \mathrm{~mL}$ of water, the dantrolene concentration is about $1 \mathrm{mM}$.

TABLE Time required to dissolve the contents of commercially available dantrolene vials (Dantrium ${ }^{\circledR}$ ) following the addition of $60 \mathrm{~mL}$ sterile water, USP, at water temperatures between $15^{\circ} \mathrm{C}$ and $40^{\circ} \mathrm{C}$

\begin{tabular}{llllllll}
\hline & \multicolumn{7}{l}{ Temperature $\left({ }^{\circ} \mathrm{C}\right)$} \\
Time (in seconds) to achieve a: & 15 & 20 & 25 & 30 & 37 & 40 \\
\hline Small particle suspension & 70 & 90 & 60 & 50 & 60 & - \\
Clear solution & $>180$ & $>180$ & 100 & 60 & 70 & 30 \\
\hline
\end{tabular}

Vials were shaken manually and observed continuously. Every 30 sec, shaking was stopped for a five-second observation period. All data were single trials. At $40^{\circ} \mathrm{C}$, vial contents went into solution without an observable intermediate suspension stage.

perature of water added to the Dantrium ${ }^{\circledR}$ vial (Table). In contrast, the time required to produce a clear solution was strongly temperature dependent. Clear solutions did not form within $180 \mathrm{sec}$ with 60 $\mathrm{mL}$ water at $15^{\circ} \mathrm{C}$ or $20^{\circ} \mathrm{C}$. These suspensions were still cloudy when visually inspected 60 min later.

\section{Discussion}

Dantrolene solubility increases linearly with increasing temperature between 20 and $40^{\circ} \mathrm{C}$. Because infusing iv fluids hotter than $40^{\circ} \mathrm{C}$ could cause red blood cell lysis and local tissue burns, we did not test higher water temperatures. ${ }^{2,3}$ However, reconstituting dantrolene with $40^{\circ} \mathrm{C}$ water greatly speeds drug preparation.

During simulated clinical conditions, a clear solution of dantrolene never formed after the addition of $60 \mathrm{~mL}$ sterile water (the recommended volume) at 
$15^{\circ} \mathrm{C}$ or $20^{\circ} \mathrm{C}$. It is not known if injecting a dantrolene suspension rather than a solution would present patient safety issues. In general, however, drugs administered in aqueous solution are available at cellular sites of action more quickly than drugs administered as fine particles in suspension. ${ }^{7}$

Warm sterile water for injection is rarely available in the operating room. Hospitals frequently store the sterile water for dantrolene reconstitution in the operating suite, which has an average air temperature of $18-21{ }^{\circ} \mathrm{C} .{ }^{6}$ Procter \& Gamble recommends that dantrolene be reconstituted with water at "room temperature"; one doubts that the manufacturer fully appreciates the frosty ambiance of most North American operating rooms. An iv fluid warming device could be used to warm the sterile water for dantrolene dissolution to $40^{\circ} \mathrm{C}$. Alternatively, many operating rooms maintain $37^{\circ} \mathrm{C}$ warming cabinets for the storage of saline and sterile water irrigating solutions and cotton blankets. Sterile water for injection, USP could be stored in one of these warming cabinets.

Heat also increases the aqueous solubility of mannitol, the other active ingredient in Dantrium ${ }^{\circledR}$. A vial of Dantrium ${ }^{\circledR}$ contains 3,000 mg mannitol and 20 mg dantrolene; thus, the ingredients are 99\% mannitol by weight. According to the mannitol package insert, mannitol crystals precipitate if the solution is chilled. ${ }^{\mathrm{A}}$ Heating is the recommended way to redissolve crystal-containing mannitol containers. ${ }^{\mathrm{A}}$

Paradoxically, the time saved by using $40^{\circ} \mathrm{C}$ water to reconstitute dantrolene could decrease heat gain in $\mathrm{MH}$ patients. During fulminant $\mathrm{MH}$, core temperature can increase as much as $1^{\circ} \mathrm{C}$ every five minutes. ${ }^{1}$ In a $70-\mathrm{kg}$ adult, this translates to about $14 \mathrm{kcal} \cdot \mathrm{min}^{-1}$ heat production. ${ }^{\mathrm{B}}$ The $420-\mathrm{mL}$ of water needed to mix a $2-\mathrm{mg} \cdot \mathrm{kg}^{-1}$ dose for a $70-\mathrm{kg}$ patient contains 8.4 $\mathrm{kcal}$ more heat at $40^{\circ} \mathrm{C}$ than at $20^{\circ} \mathrm{C}$. Using $40^{\circ} \mathrm{C}$ water would be thermally neutral if one saved $36 \mathrm{sec}$ in dantrolene preparation time $(5.1 \mathrm{sec} / \mathrm{vial})$ and would result in net heat loss if more time were saved.

At $20^{\circ} \mathrm{C}$, dantrolene is nearly insoluble at $\mathrm{pH}$ values below 8.8. $\mathrm{pH}$ adjustments of the dantrolene diluent are unlikely to improve the drug preparation time.

\footnotetext{
A Mannitol iv package insert, Abbott Laboratories, North Chicago, IL, USA, CAbbott, 1994, revised 2/1998.

B For this rough approximation, we assumed that total body water is $100 \%$ rather than $67 \%$ of body weight. One kilocalorie increases the temperature of $1 \mathrm{~kg}$ by $1^{\circ} \mathrm{C}$. If body temperature can increase $0.2^{\circ} \mathrm{C}$ per minute during fulminent $\mathrm{MH}\left(1^{\circ} \mathrm{C}\right.$ every five minutes), then a $70-\mathrm{kg} \mathrm{MH}$ patient can produce 14 kcal of heat per minute.
}

Dantrium is packaged to have $\mathrm{pH} 9.5$ after reconstitution with sterile water USP, and higher $\mathrm{pH}$ values might cause tissue damage. Although dantrolene is more soluble in THAM than in sterile water, the effect is small and THAM is quite expensive. THAM does not appear to be a cost-effective adjuvant in dantrolene preparation. In addition, the effects of THAM buffer on the stability and potency of dantrolene would need to be determined before the use of a THAM buffer diluent could be recommended.

Prompt dantrolene injection is the cornerstone of effective MH therapy. Precious time can be lost if one is not prepared for the practical problem of dantrolene reconstitution. We recommend that the sterile water for dantrolene reconstitution either be stored in a $40^{\circ} \mathrm{C}$ operating room warming cabinet or that equipment be available for warming the water rapidly to $40^{\circ} \mathrm{C}$, since dantrolene is far more soluble in warm water than cold.

\section{References}

1 Gronert GA, Antognini JF, Pessah IN. Malignant hyperthermia. In: Miller RD (Ed.). Anesthesia, 5th ed. New York: Churchill Livingstone Inc., 2000: 1033-52.

2 Leaman PL, Martyak GG. Microwave warming of resuscitation fluids. Ann Emerg Med 1985; 14: 876-9.

3 Sieunarine K, White GH. Full-thickness burn and venous thrombosis following intravenous infusion of microwave-heated crystalloid fluids. Burns 1996; 22: 568-9.

4 Drechsler H. Zur. [On the treatment of malignant hyperthermia. A simple method of preparing a dantrolene sodium solution (author's transl)] German. Anaesthesist 1981; 30: 257-8.

5 Jansen ACA, Hilbers HW, Ni XR, van Helden SP, Janssen LHM. Some physical-chemical properties of dantrolene and two of its analogues. Int J Pharm 1991; 75: 193-9.

6 Blitt CD. Monitoring the anesthetized patient. In: Barash PG, Cullen BF, Stoelting RK (Eds.). Clinical Anesthesia, 3rd ed. Philadelphia: Lippencott-Raven Publishers, 1997: 563-85.

7 Benet LZ, Kroetz DL, Sheiner LB. Pharmacokinetics. The dynamics of drug absorption, distribution, and elimination. In: Hardman JG, Limbird LE (Eds.) Goodman \& Gilman's The Pharmacological Basis of Therapeutics, $9^{\text {th }}$ ed. New York: McGraw-Hill, 1996: 3-27. 